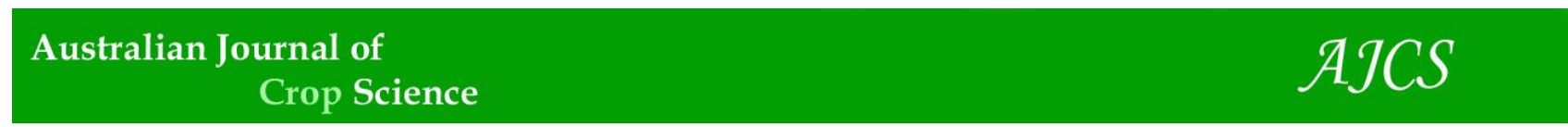

AJCS 10(12):1662-1668 (2016)

ISSN:1835-2707

doi: 10.21475/ajcs.2016.10.12.p7737

\title{
Harvesting time influences fruit removal force, moisture, oil content, free fatty acids and peroxide in the oil of Frantoio and Manzanilla olive cultivars
}

\author{
Bassam Alowaiesh $^{1,2^{*}}$, Zora Singh ${ }^{1}$, Stanley George Kailis ${ }^{3}$ \\ ${ }^{1}$ Curtin Horticulture Research Laboratory, Department of Environment and Agriculture, School of Sciences, \\ Faculty of Science and Engineering, Curtin University, GPO Box U 1987, Perth 6845, Western Australia, \\ Australia \\ ${ }^{2}$ Olive Research Unit,Camel and Range Research Center Sakaka, Al Jouf, Saudi Arabia \\ ${ }^{3}$ School of Plant Biology, The University of Western Australia, Crawley, Western Australia, Australia
}

*Corresponding author: bassamfaris@hotmail.com

\begin{abstract}
Harvesting time at different ripening stages of olive fruit may influence quality attributes of olive oil. Therefore, the effects of five different harvesting times (mid- and late-April, mid- and late-May and mid-June) on fruit removal force, moisture, oil content, free fatty acids and peroxide in the oil of Frantoio and Manzanilla olive cultivars grown in south-western Australia was investigated during 2013 and 2014. The fruit of cv. Manzanilla showed significantly ( $p \leq 0.05)$ higher fruit removal force, moisture content (\%) and oil content in dry weight $(\%)$ than cv. Frantoio. Furthermore, lowest moisture and oil content were observed in the driest harvest year, in 2014. The free fatty acid content showed significant $(p \leq 0.05)$ increase and peroxide value decreased with the delay in harvesting from first to fifth periods in both the years, regardless of the cultivars. Overall, harvesting of olive fruit during the early part of winter delivered olive oil content with better quality and climatic conditions such as water stress have negatively influenced the quality attributes of olive oil.
\end{abstract}

Keywords: Olea europaea; quality; ripening index; peroxide, free fatty acids olive, fruit removal force.

Abbreviations: cv_cultivar; FRF_Fruit removal force; HDL_High Density Lipoprotein; LDL_Low Density Lipoprotein; WA_Western Australia; NSW_New South Wales.

\section{Introduction}

Olive oil is one of the oldest produced foods providing perfect balance of aroma, taste, flavour and health benefits. The dietary importance of olive oil and health benefits are due to both fatty acid composition and minor compounds like polyphenols, tocopherols, sterols and carotenoids (La Lastra et al., 2001). It is also a good source of nutrients, vitamin E, beta-carotene and minerals (Reichelt and Burr, 2000). Psaltopoulou et al. (2004) reported that consumption of olive oil showed beneficial effect on arterial blood pressure by reducing levels of harmful cholesterol LDL (Low Density Lipoprotein), without affecting beneficial HDL (High Density Lipoprotein) cholesterol. .

A significantly higher percentage of oil was reported in early ripening olive fruit (Salvador et al., 2001; Lavee and Wodner, 2004). Lavee and Wodner (2004) observed uniform oil content in the mesocarp of black matured fruit of Barnea and Manzanilla cultivars regardless of size and level of fruit yield. Similar results were reported by Beltran et al. (2004), however they claimed that the oil content may vary due to climatic conditions such as lower rainfall, which may cause lower oil and higher dry matter content in olive fruit. Maximum oil content was reported between $60^{\text {th }}$ to $75^{\text {th }}$ days after the commencement of the ripening process (Camposeo et al., 2013). Reduction in the value of most of the analytical parameters such as peroxide value, pigments, sensory scores, oleic acid and total sterols; and increase in the free acidity and linoleic acid were observed during ripening of cv. Cornicabra olive (Salvador et al., 2001).

Frantoio and Manzanilla are two olive (Olea europaea L.) cultivars originating from Spain and Italy respectively. Both are widely cultivated in the olive growing countries of the world including Australia due to their high productivity, fruit and oil quality and their agronomic adaptability. These cultivars have also been cultivated in south-western Australia for several decades (Taylor and Burt, 2007). Olive oil from the major cultivars grown in Australia does not meet all the limits set by international standards for some parameters (Mailer et al., 2010). There are limited studies reported on the effect of harvesting time on oil content from New South Wales (NSW), Australia. From these reports it has been noted that depending upon the cultivars, the olive fruit oil content increases rapidly until fruit maturity with different rate among cultivars to reach a maximum percentage of oil content (Mailer et al., 2007 and Zeleke et al., 2012). Despite the enormous potentiality and economic importance of growing olives in Western Australia (WA) (Kailis and Harris, 1999), there is no information available on the effect of harvesting time on chemical composition and properties of the olive fruit and extracted oil according to the ripening stages of the fruit. Therefore, the current study was conducted with the aim of determining the optimal harvesting time of olive cvs. Frantoio and Manzanilla in south-western Australia and investigating the effect of different harvesting times/fruit 
ripening stages (April to June) on fruit removal force, fruit moisture and oil content, levels of free fatty acid, peoxide in the oil.

\section{Results}

\section{Effect of harvesting time on fruit removal force}

The mean of fruit removal force significantly decreased irrespective of the cultivar from first to fifth harvest $(5.85 \mathrm{~N}$ to $4.00 \mathrm{~N}$ ) in 2013. A similar trend in reduction of fruit removal force was also noticed in 2014. The highest removal force $(6.20 \mathrm{~N})$ was in first harvesting time of cv. Manzanilla in 2013 and the lowest $(2.47 \mathrm{~N})$ was in fifth harvesting time of cv. Frantoio in 2014 (Fig. 1). Moreover, it was found that the mean fruit removal force was significantly $(p \leq 0.05)$ higher in cv. Manzanilla than cv. Frantoio (1.71- and 1.43fold in 2013 and 2014 respectively).

\section{Effect of harvesting time on fruit moisture (\%)}

When averaged over cultivars, the mean moisture percentage in the fruit declined from first to fifth harvest in 2013 and 2014 (from 57.57 to $54.08 \%$ and from 54.69 to $51.48 \%$ respectively). The highest fruit moisture was noted in first harvesting time of Manzanilla in 2013 (62.35\%) and the lowest was in fifth harvesting time of cv. Frantoio in 2014 $(47.25 \%$ ) (Fig. 2). When averaged over treatments, the mean fruit moisture $(\%)$ was significantly $(p \leq 0.05)$ higher in cvs. Manzanilla than Frantoio (1.19-fold in both years). There was a significant $(p \leq 0.05)$ interaction between harvesting time and cultivars for fruit moisture (\%) in both years.

\section{Effect of harvesting time on oil content in the fruit (\% dry weight)}

The mean of oil percentage in olive fruit significantly ( $p \leq$ 0.05 ) increased (1.07-fold and 1.10-fold respectively) irrespective of cultivars from first to fifth harvesting time in 2013 and 2014. The oil accumulated faster in cvs. Manzanilla than Frantoio from first to fifth harvesting time in both years. However the highest oil percentage was noted in fifth harvesting time in cv. Frantoio during 2013 and 2014 (39.05\% and $38.55 \%$ respectively) (Fig. 3). Meanwhile, in cv. Manzanilla, fourth and fifth harvest time resulted in higher oil percentage both years $(38.65 \%, 38.58 \%$ in 2013 and $38.05 \%, 37.85 \%$ in 2014 respectively). Irrespective of the harvesting time, the mean oil percentage in cv. Manzanilla (\% dry weight) was significantly $(p \leq 0.05)$ higher than Frantoio (1.01-fold) in both the years. There was a significant $(p \leq 0.05)$ interaction between harvest time and cultivars in both years for percentage of oil (\% dry weight).

Effect of harvesting time on free fatty acids in virgin olive oil (\%)

Irrespective of the cultivars, the mean free fatty acids (\%) in virgin olive oil increased significantly $(p \leq 0.05)$ from first to fifth harvest in 2013 (from $0.27 \%$ to $0.37 \%$ ) and in 2014 (from $0.28 \%$ to $0.38 \%$ ). The concentration of free fatty acids $(\%)$ increased significantly $(p \leq 0.05)$ with delay in harvest from first to fifth in cv. Manzanilla (from $0.28 \%$ to $0.37 \%$ in 2013 and $0.32 \%$ to $0.37 \%$ in 2014) and cv. Frantoio (from $0.25 \%$ to $0.37 \%$ in 2013 and $0.24 \%$ to $0.38 \%$ in 2014) (Fig. $4)$. When averaged over harvest treatments, the mean free fatty acids $(\%)$ was significantly $(p \leq 0.05)$ higher in cv. Manzanilla (0.33\% and $0.34 \%)$ than cv. Frantoio $(0.32 \%$ and $0.30 \%$ ) during 2013 and 2014 respectively. The interaction between harvesting time and cultivars for free fatty acid in the oil during 2013 was non-significant; whilst in 2014, the interaction was significant $(p \leq 0.05)$.

\section{Effect of harvesting time on peroxide value in virgin olive oil}

The peroxide value in virgin olive oil decreased significantly $(p \leq 0.05)$ from first to fifth harvest $(0.47$-fold in 2013 and 0.59 -fold in 2014). The peroxide value in virgin olive oil of cv. Manzanilla decreased significantly $(p \leq 0.05)$ with delay in harvest from first to fifth (from 6.65 to 3.28 meq $\mathrm{O}_{2} \mathrm{~kg}^{-1}$ in 2013 and from 3.28 to 5.31 meq $\mathrm{O}_{2} \mathrm{~kg}^{-1}$ in 2014) (Fig. 5). Similar trend was also observed in cv. Frantoio in both years. The Frantoio virgin olive oil showed significantly $(p \leq 0.05)$ higher peroxide value than cv. Manzanilla (1.32- and 1.08fold in 2013 and 2014 respectively). There was a significant $(p \leq 0.05)$ interaction between harvesting time and cultivars in both years for peroxide value in oil.

\section{Discussion}

Harvesting time or the ripening status of the fruit at harvest time was suggested as one of the important factor influencing the quality of virgin olive oil (Koutsaftakis et al., 1999). Over-ripening of olive fruit increases both oil yield and the acidity level, but limited amounts of oil can be removed from the fruit if harvested too early. Moreover, the sterol composition also depends on the ripening stage of the fruit (Anastasopoulos et al., 2011). Delay in harvesting time resulted in reduction of FRF in both the years, regardless of cultivar (Fig. 1). The FRF is linearly correlated to the stage of fruit growth and reduces with the advancement of ripening (Lavee et al., 1973 and Lavee et al., 1982). The reduction of FRF could also be ascribed to the level of endogenous ethylene which increases with the development of the fruit and contributes in reducing the FRF through the release of ethylene (Lavee et al., 1982). The genotypic differences cause the variability in FRF between cultivars which has also been claimed by early researchers (Lavee and Haskal, 1976). The thickness of stalks differs among cultivars that also differ according to the size of the fruit within the cultivar which shows a declining trend with the progress of fruit growth (Lavee et al., 1982).

Fruit mositure content declined with the delayed harvesting time in both cultivars during two consective years (Fig.2). Water is a major component of olive fruit comprising more than half of the total fruit weight and varies according to the variation of seasonal rainfall and cultivar (Beltrán et al., 2004). From the current study it was revealed that the level of moisture was low in 2014 when the rainfall was low during the growing period of the fruit in that year. The ripening of olive is affected by the cultivar and the environmental factors (Lavee et al., 1990). The least moisture content was observed in the most dry harvest year (2014) due to water stress conditions. This phenomenon was also supported by Lavee and Wodner (1991) and Ortega et al. (2001). On the other hand, a decrease of moisture content can also be related to the progressive increase of the oil content during fruit maturation (Sánchez and Fernández, 1991).

Delayed harvesting time resulted in increased oil content (\% dry weight) in cv. Manzanilla and Frantoio during both the years (Fig. 3). Maximum oil content was noted in the fruit harvested in $4^{\text {th }}$ harvest or during late May. Availability of water or its stress largely influences the development and oil content of the olive fruit (Lavee et al., 1982, 1990; Barone et al., 1994; Tombesi, 1994 and Inglese et al., 1996). The olive cultivars also show differences in oil content among growing 
Table1. Harvesting time of cvs. Frantoio and Manzanilla olive fruit during 2013 and 2014.

\begin{tabular}{lcc}
\hline Harvesting Time & Harvesting time 2013 & Harvesting time 2014 \\
\hline First (H1) & 17th April & 15th April \\
Second (H2) & 30th April & 29th April \\
Third (H3) & 14th May & 13th May \\
Fourth (H4) & 28th May & 29th May \\
Fifth (H4) & 11th Jun & 12th June \\
\hline
\end{tabular}

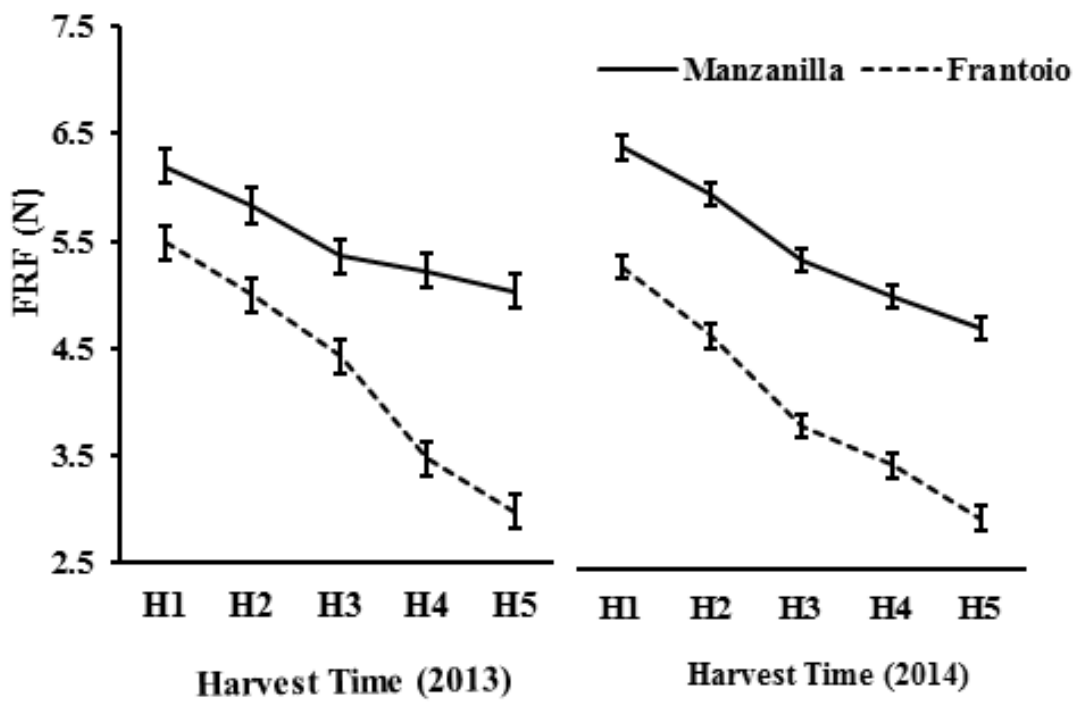

Fig 1. Effects of different harvesting time on the fruit removal force in cvs. Frantoio and Manzanilla olives during 2013 and 2014. Vertical bars represent LSD $(P \leq 0.05) . \mathrm{n}=$ four replicates $(20$ fruits per replicate).

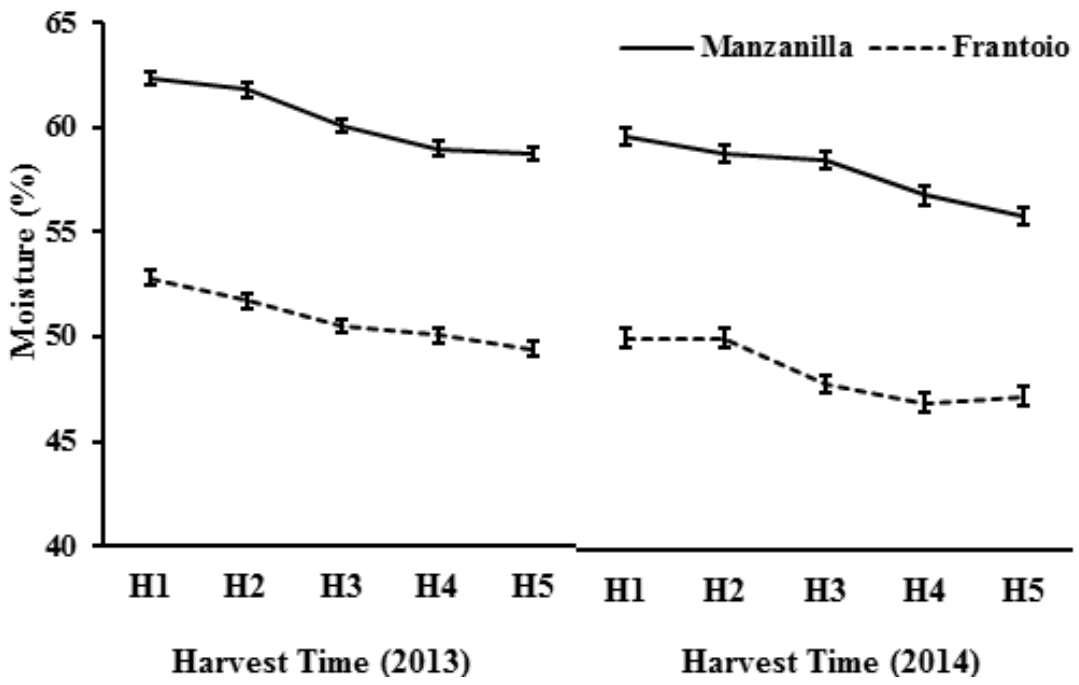

Fig 2. Effects of different harvesting time on the levels of fruit moisture (\%) of cvs. Frantoio and Manzanilla olives during 2013 and 2014.Vertical bars represent $\operatorname{LSD}(P \leq 0.05) . \mathrm{n}=$ four replicates.

areas and year of cultivation (Barranco et al., 2000). Oil content in olive fruit showed an increasing trend until late harvesting time in both cvs. Frantoio and Manzanilla (Fig. 3). A similar observation was reported by Beltrán et al. (2004). Oil content at the end of the ripening period showed insignificant $(p \leq 0.05)$ differences and plateaued due to lower temperature during that period in both years while the autumn rains reduced the relative oil content due to rapid changes in water content of fruit and flesh (Beltrán et al., 2004). The two cultivars also differed significantly for oil content on a dry weight basis which is a genotypic characteristic (Beltrán et al., 2004). The lowest oil content was found in the low rainfall crop year, 2014, which is similar to the findings reported by Ortega et al. (2001) for water stress conditions. A significant increase was noticed in free fatty acids in the oil with delayed harvesting time in both cultivars during the two years and the trend was reverse in the levels of peroxide in the oil (Fig. 4 and 5). The free fatty acids at the later stage of ripening may also increase with the increase of lypolytic enzyme activity within the flesh 


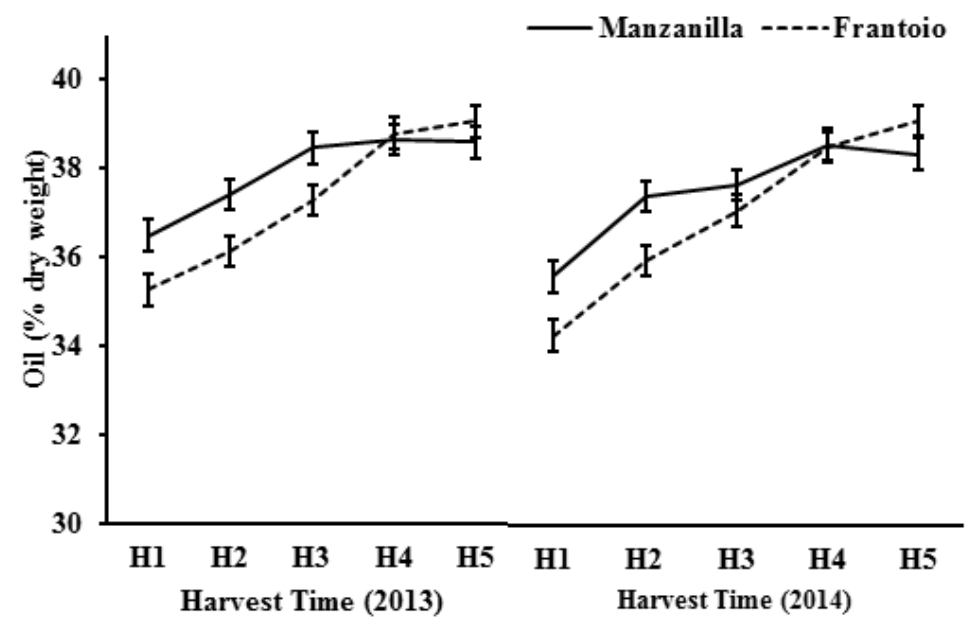

Fig 3. Effects of different harvesting time on concentration of oil (\% dry weight) in cvs. Frantoio and Manzanilla olives during 2013 and 2014. Vertical bars represent as $\operatorname{LSD}(P \leq 0.05) . \mathrm{n}=$ four replicates.

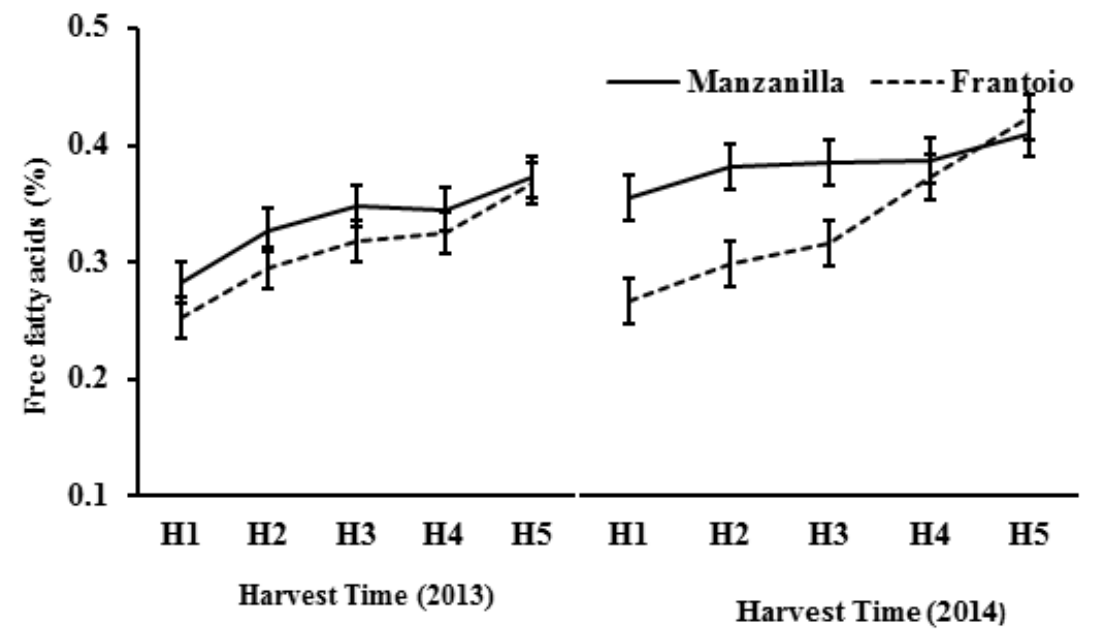

Fig 4. Effects of different harvesting time on the free fatty acids (\%) in the oil of cvs. cvs. Frantoio and Manzanilla olives during 2013 and 2014. Vertical bars represent LSD $(P \leq 0.05) . \mathrm{n}=$ four replicates.

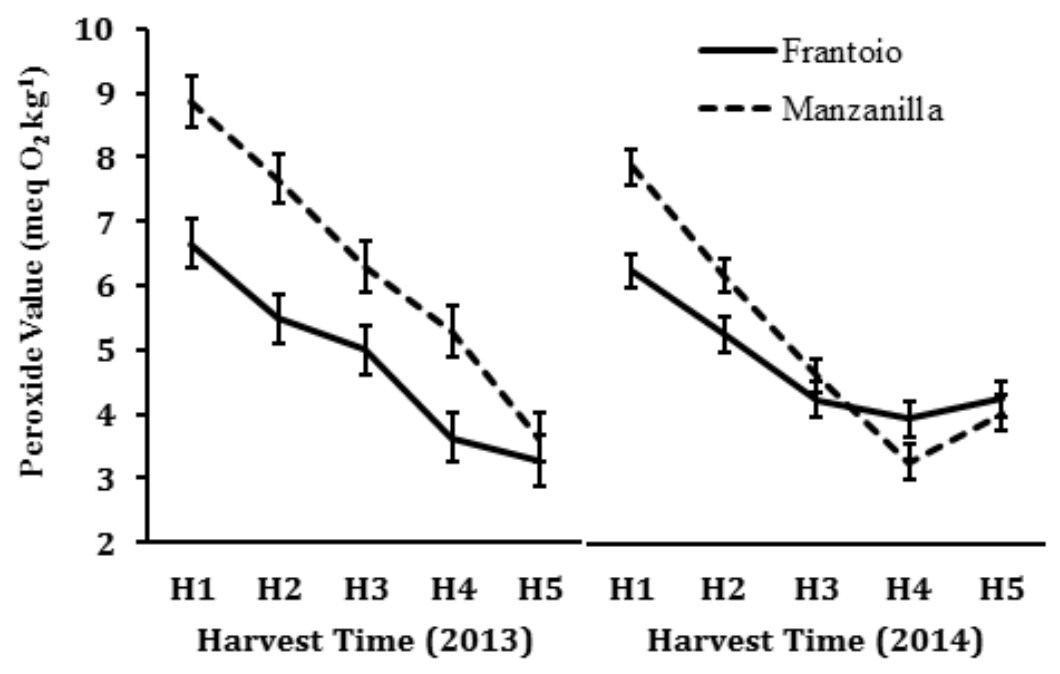

Fig 5. Effects of different harvesting time on peroxide value $\left(\right.$ meq $\left.\mathrm{O}_{2} \mathrm{~kg}^{-1}\right)$ in virgin olive oils of cvs. Frantoio and Manzanilla olives during 2013 and 2014. Vertical bars represent LSD $(P \leq 0.05) . \mathrm{n}=$ four replicates. 
(Anastasopoulos et al., 2011). The trend of lowering peroxide value might be ascribed to the decreased activity of lipoxygenase enzymes which have been reported by Gutierrez et al. (1999), Salvador et al. (2003), Baccouri et al. (2008) and Anastasopoulos et al. (2011). The present study also revealed similar results where the fruit harvest in 2014 faced a water stress due to low rainfall during its growing period. The oils of cv. Manzanilla showed higher levels of free fatty acids. Furthermore, higher levels of peroxide value, were observed in cv. Frantoio (Fig.10)

\section{Materials and Methods}

\section{Plant materials}

The experiment was conducted on 15 years old, centralleader-shaped, uniform size olive trees cv. Frantoio and Manzanilla. The trees were spaced at $7 \mathrm{~m} \times 7 \mathrm{~m}$ with a tree density of 358 trees $\mathrm{ha}^{-1}$. The experimental trees received supplementary irrigation (200-600 L per tree) for five months per year using drippers placed around the trees delivering water flow of $1.2 \mathrm{~L} \mathrm{~h}^{-1}$ commencing from December to May. All the experimental trees received similar cultural practices including fertilization, plant protection and pruning except the harvesting time.

\section{Experimental location and climatic conditions}

The experiment was conducted in Talbot Olive Grove at York ( $\left.31^{\circ} 52^{\prime} 44^{\prime \prime} \mathrm{S}, 116^{\circ} 45^{\prime} 57^{\prime \prime} \mathrm{E}\right)$ Western Australia. York is located in a Mediterranian climate zone of Western Australia which experiences distinctly dry, long, hot summers and cool, wet winters. The mean annual daily minimum temperature is $10.5^{\circ} \mathrm{C}\left(50.9^{\circ} \mathrm{F}\right)$. The hottest month is January with a mean maximum temperature of $33.6{ }^{\circ} \mathrm{C}$ $\left(92.5^{\circ} \mathrm{F}\right)$, while the coolest month is July with a mean minimum temperature of $5.3^{\circ} \mathrm{C}\left(41.5^{\circ} \mathrm{F}\right)$. York has a mean annual rainfall of 403.6 millimetres. The wettest month being July with 71.8 millimetres and the driest is December with 11.3 millimetres rainfall. The temperatures and rainfall are based on data from 1996 to 2014 (Australian Bureau of Meteorology, 2015, http://www.bom.gov.au). During the growing period of olive fruit, the lowest rainfall ( 0 to 5.5 $\mathrm{mm}$ ) was observed from December to March 2014, when the rainfall ranged from 2.8 to $56.7 \mathrm{~mm}$ in 2013 . The amount of rainfall increased during the development and maturation phase of the fruit from April to June when it ranged from 46.6 to $89.3 \mathrm{~mm}$ and 4.8 to $68.8 \mathrm{~mm}$ in 2014 and 2013 respectively. Higher levels of maximum and minimum temperature were about $34^{\circ} \mathrm{C}$ and $16^{\circ} \mathrm{C}$, respectively.

\section{Design of experiment and treatments}

Fruit were harvested from trees at five different times commencing in autumn as mid- and late-April, mid- and lateMay and early winter, mid-June for two consective years 2013 and 2014 (Table 1). The cultivars included in this experiment were Frantoio and Manzanilla. The experiment was laidout by following two-factor (harvesting time and cultivar) factorial Randomized Complete Block Design (RCBD) with 4 replications. Five olive trees were considered as an experimental unit. Fruit removal force, moisture content, oil per cent in the fruit on dry weight basis were determined in both cultivars on each harvesting time during 2013 and 2014. Free fatty acids and peroxide levels were determined from the oil extracted from the fruit harvested on each harvest date in both cultivars in 2013 and 2014.

\section{Collection of olives and preparation of virgin olive oil}

Olive fruit (composite sample of 1.5 to $2 \mathrm{Kg}$ ) were harvested by hand from five representative trees included in each replicate of cvs. Frantoio and Manzanilla The fruit were harvested at five different ripening times from mid-autumn to early winter (April to mid-June) at fortnightly intervals in 2013 and 2014 (Table.1). Virgin olive oil was prepared from the collected fruit by following the method of Rivas et al. (2013) .

\section{Fruit removal force (FRF)}

The FRF was determined by using a texture profile analyser (TPA Plus, AMETEK Lloyd Instruments Ltd, Hampshire, $\mathrm{UK})$, equipped with horizontal square base table $(15 \mathrm{~cm} \times 15$ $\mathrm{cm})$ and interfaced to a personal computer with Nexygen ${ }^{\circledR}$ software. FRF was detrmined from 20 randomly selected fruit per replicate and expressed as newton $(\mathrm{N})$.

\section{Moisture content (\%) of olive fruit}

The olive fruit moisture content was determined according to IOC (2011) by using $60 \mathrm{~g}$ healthy and randomly selected olive fruit. The fruit were ground with a hammer mill and dried in a forced air oven at $105^{\circ} \mathrm{C}$ for approximately $8-10$ hours until the weight was constant. Mositure content in the fruit was expressed as percentage.

\section{Olive oil content (\% dry basis)}

Olive oil percentage was determined from freshly harvested olive fruit by following the method described by Avidan et al. (1999) with some modifications. Ten grams of olive fruit paste from each replicate of cvs. Frantoio and Manzanilla was taken in small scintillation glass vials and dried in an oven at $80^{\circ} \mathrm{C}$ for $24 \mathrm{~h}$ to constant weight. Then $5 \mathrm{~g}$ of each dried sample was transferred to $25 \times 100 \mathrm{~mm}$ glass tubes and $10 \mathrm{ml}$ of petroleum ether at $60-80^{\circ} \mathrm{C}$ was added, and the mixture homogenised at medium speed for $30 \mathrm{sec}$ with a vortex mixer (Heidolph, Reax Top, Australia). The content was rinsed with $5 \mathrm{ml}$ petroleum ether and agitated overnight with a rotator shaker (Ratek Orbital Mixer, Australia). The following day each extract was passed through a paper filter and again rinsed with $5 \mathrm{ml}$ petroleum ether. This dissolved oil was recovered by evaporating off the petroleum ether at $40^{\circ} \mathrm{C}$.

\section{Determination of free fatty acids}

The free fatty acid (\%) in the oil was determined according to the EEC (1991). The virgin olive oil $(10 \mathrm{~g})$ was dissolved in $50 \mathrm{ml}$ of the solvent mixture (1:1 of $95 \%$ (V/V) ethanol and diethyl ether) and titrated with a solution of potassium hydroxide to a pink colour that persisted for at least $10 \mathrm{sec}$. Free fatty acids in the oil expressed as percent of oleic acid.

\section{Peroxide value of oil}

Peroxide value of the virgin olive oil fraction was determined according to EEC (1991) method under artificial or diffused daylight. The virgin olive oil (1-2 g) was added to $10 \mathrm{ml}$ of chloroform, $15 \mathrm{ml}$ of acetic acid and $1 \mathrm{ml}$ of potassium iodide (KI) in a $250 \mathrm{ml}$ flask. The mixture was shaken for 1 minute and then left for 5 minutes at a temperature of 15 to $25^{\circ} \mathrm{C}$ in the dark. Then $75 \mathrm{ml}$ of distilled water was added and the mixture titrated with the sodium thiosulphate solution $(0.002$ 
$\mathrm{N})$. During titration, the flask and contents were shaken. free fatty acids $(\%)$ in virgin olive oils. Peroxide value expressed in milli equivalents of active oxygen per kilogram of olive oil (meq $\mathrm{O}_{2} \mathrm{Kg}^{-1}$ ).

\section{Statistical analysis}

All the experimental data were subjected to two-way analysis of variance (ANOVA) using GenStat 14 (release 14.1; Lawes Agricultural Trust, Rothamsted Experimental Station, Harpenden, UK). The effects of various harvesting time treatments, cultivars and their interactions were assessed within ANOVA and least significant differences (Fisher's LSD) were calculated following significant $(P \leq 0.05)$ F-test. All the assumptions of analysis were checked to ensure validity of statistical analysis. The data on various parameters over two years were not pooled because error mean squares over years were found to be heterogeneous.

\section{Conclusion}

Fruit removal force, moisture content $(\%)$ and mean oil content in dry weight (\%) was higher in cv. Manzanilla than Frantoio. Moisture and oil content were lower during 2014, which was a relatively moredry harvest year than 2013 . At the later stage of ripening the increase of free fatty acids was observed which may be ascribed to the increase of lipolytic enzyme activity and lowering trend of peroxide value may be due to the decreased activity of lipoxygenase enzymes. Overall, the harvesting of olive fruit during the early part of winter delivered olive oil with better quality and climatic conditions such as water stress negatively influences the quality attributes of olive oil. It could be concluded that the most suitable time for olive harvesting in South Western Australia is late-May to mid-June.

\section{Acknowledgements}

Bassam Alowaiesh gratefully acknowledges the Food and Agriculture Organization of the United Nations (FAO) and the Ministry of Agriculture in Saudi Arabia for financial support during his $\mathrm{PhD}$ research. We are thankful to $\mathrm{Mr}$. Frederik Altenstadt, Talbot Olive Grove, York, Western Australia for generously providing olive trees and fruit for the experiment and Ms S Petersen for technical assistance.

\section{References}

Anastasopoulos E, Kalogeropoulos N, Kaliora A, Kountouri A, Andrikopoulos N (2011) The influence of ripening and crop year on quality indices, polyphenols, terpenic acids, squalene, fatty acid profile, and sterols in virgin olive oil (Koroneiki cv.) produced by organic versus non-organic cultivation method. J Food Sci Tech. 46: 170-178.

Avidan B, Ogrodovitch A, Lavee S (1999) A reliable and rapid shaking extraction system for determination of the oil content in olive fruit. Acta Hortic. 474: 653-658.

Baccouri O, Guerfel M, Baccouri B (2008) Chemical composition and oxidative stability of Tunisian monovarietal virgin olive oils with regard to fruit ripening. Food Chem. 109: 743-754.

Barone E, Gullo G, Zappia R, Inglese P (1994) Effect of crop load on fruit ripening and olive oil (Olea europaea L.) quality. J Hort Sci. 69: 67-73.

Barranco D, de Toro C, Oria M, Rapoport H. (2000) Monopotassium phosphate $\left(\mathrm{PO}_{4} \mathrm{H}_{2} \mathrm{~K}\right)$ for olive fruit abscission. Acta Hortic. 586: 263-266.
Beltrán G, del Rio C, Sánchez S, Martínez L (2004) Influence of harvest date and crop yield on the fatty acid composition of virgin olive oils from cv. Picual. J Agric Food Chem. 52: 3434-3440.

Camposeo S, Vivaldi G, Gattullo C (2013) Ripening indices and harvesting times of different olive cultivars for continuous harvest. Sci Hort.151: 1-10.

EEC (1991) European Union Commission Regulation (2568/1991). Characteristics of olive and olive pomace oils and their analytical methods. Off J Eur Commun. 248: 1-5

Gutiérrez F, Jimenez B, Ruiz A，Albi M (1999) Effect of olive ripeness on the oxidative stability of virgin olive oil extracted from the varieties Picual and Hojiblanca and on the different components involved. J Agric Food Chem. 47: 121-127.

IOC, (2011) COI/ OH/ Doc. No 1 November [on line date 1/3/14] (http://www.internationaloliveoil.org/). Madrid.

Inglese P, Barone E, Gullo G (1996) The effect of complementary irrigation on fruit growth, ripening pattern and oil characteristics of olive (Olea europaea L) cv. Carolea. J Hort Sci. 71:257-263.

Kailis S, Harris D (1999) Potential for European olive growing in Western Australia. Acta Hortic. 474: 771-775.

Koutsaftakis A, Kotsifaki F, Stefanoudaki E (1999) Effect of extraction system stage of ripeness and kneading temperature on the sterol composition of virgin olive oils. J Amer Oil Chem Soc. 76: 1477-1481.

La Lastra, C, Alarcón D, Barranco M, Motilva V, Herrerías J (2001) Mediterranean diet and health: Biological importance of olive oil. Curr Pharm Design. 7: 933-950.

Lavee S, Avidan B, Ben-Tal Y (1982) Effect of fruit size and yield on the fruit removal force within and between cultivars. Sci Hort. 286:441-451.

Lavee S, Barshi G, Haskal A (1973) Natural fruit drop and induced abscission to facilitate mechanical harvesting of Manzaillla and Souri olives. Sci Hort. 1: 63-75.

Lavee S, Haskal A (1976) Further field studies of the mode of application and efficiency of various ethylene-releasing chemicals to facilitate olive fruit harvest. Riv Ortof Ital. 60: 166-175.

Lavee S, Nashef M, Wodner M, Harshemesh H (1990) The effect of complementary irrigation added to old olive trees (Olea europaea L.) cv. Souri on fruit characteristics, yield and oil production. J Hort Sci. 4:135-138.

Lavee S, Wodner M (1991) Factors affecting the nature of oil accumulation in fruit of olive. J Hort Sci. 66: 583-591.

Lavee S, Wodner M (2004) The effect of yield, harvest time and fruit size on the oil content in fruits of irrigated olive trees (Olea europaea) cvs. Barnea and Manzanillo. Sci Hort. 99: 267-277.

Mailer R, Ayton J, Conlan D (2007) Influence of harvest timing on olive (Olea europaea) oil accumulation and fruit characteristics under Australian conditions. J Food Agric Enviro. 5: 58 - 63.

Mailer R J, Ayton J Graham K (2010) The influence of growing region, cultivar and harvest timing on the diversity of Australian olive oil. J Amer Oil Chem Soc. 87: 877-884.

Ortega, D, Beltr'G, Uceda M (2001) Influencia del riego en lalipogénesis del cv 'Arbequina'. Proc Symp CientificoTecnico Expoliva, Jaén. 63-71.

Psaltopoulou T, Naska A, Orfanos P, Trichopoulos D, Mountokalakis T, Trichopoulou A (2004) Olive oil, the Mediterranean diet, and arterial blood pressure: the Greek European prospective investigation into cancer and nutrition (EPIC) study. Am J Clin Nutr. 80: 1012-1018. 
Reichelt K, Burr M (2000) Extra virgin: An Australian companion to olives and olive oil. Wakefield. pp.10-14.

Rivas A, Sanchez-Ortiz A, Jimenez B, García-Moyano J, Lorenzo M (2013) Phenolic acid content and sensory properties of two Spanish monovarietal virgin olive oils. Eur J Lipid Sci Tech. 115: 621-630.

Salvador M, Aranda F, Gomez-Alonso S, Fregapane G (2003) Influence of extraction system, production year and area on Cornicabra virgin olive oil: a study of five crop seasons. Food Chem.80: 359-366.

Salvador M, Aranda F, and Fregapane G (2001) Influence of fruit ripening on Cornicabra virgin olive oil quality. A study of four successive crop seasons. Food Chem. 73: 4553.
Sánchez A, Fernández M (1991) Correlacióon entre material grasa, azucares reductores humedad en la pulpa de aceitunas. Grasas Aceites. 42: 414-419.

Taylor R, Burt J (2007) Growing olives in Western Australia. Department of Agriculture and Food, Western Australia, South Perth, WA. p 22.

Tombesi A, Pilli M, Boco M, Proietti P (1994) Evolution of olive fruit respiration, photosynthesis and oil composition during ripening. Acta Hortic. 356: 278-445.

Zeleke K, Mailer R, Eberbach P, Wünsche J (2012) Oil content and fruit quality of nine olive (Olea europaea $\mathrm{L}$.) varieties affected by irrigation and harvest times. New Zeal J Crop Hort Sci. 40: 241-252. 